\title{
Pengaruh Ukuran Perusahaan, Profitabilitas dan Auditor Switching Terhadap Audit Delay Pada Bursa Efek Indonesia
}

\author{
Annisa*, Maizul Rahmizal \\ Program Studi Akuntansi, Sekolah Tinggi Ilmu Ekonomi KBP, Kota Padang, Indonesia \\ Email: 1,*annisa@akbpstie.ac.id, ${ }^{2}$ maizulrahmizal@akbpstie.ac.id \\ Email Penulis Korespondensi: annisa@akbpstie.ac.id \\ Submitted: 17/11/2021; Accepted: 26/11/2021; Published: 30/11/2021
}

\begin{abstract}
Abstrak-Tujuan penelitian adalah mengetahui pengaruh ukuran perusahaan, profitabilitas dan auditor switching terhadap audit delay pada perusahaan manufaktur sup industri dasar dan kimia di bursa efek Indonesia (BEI). Populasi adalah 31 perusahaan manufaktur sektor industri dasar dan kimia di BEI. Menggunakan teknik purposive sampling diterapkan untuk menentukan sampel. Sampel penelitian ini adalah perusahaan manufaktur sub industri dasar dan kimia yang terdaftar di BEI dan memenuhi kriteria. Jumlah sampel yang digunakan adalah 93 laporan keuangan yang diambil berdasarkan kriteria yang telah ditentukan. Data dikumpulkan dengan metode dokumentasi yang diukur dengan skala rasio. Hasil penelitian menunjukkan bahwa ukuran perusahaan memiliki pengaruh positif dan signifikan terhadap audit delay yang di tunjukkan dengan nilai signifikan sebesar 0,0462 , profitabilitas memberikan pengaruh negatif signifikan terhadap audit delay dengan nilai alpa 0,0047 , dan auditor switching tidak memberikan pengaruh signifikan terhadap audit delay dengan alpa 0,5687 .
\end{abstract}

Kata Kunci: Profitabilitas; Ukuran Perusahaan; Auditor Switching; Audit Delay Abstract-The purpose of this study was to determine the effect of company size, profitability and auditor switching on audit delay
in basic industrial and chemical soup manufacturing companies on the Indonesian Stock Exchange (BEI). The population is 31
manufacturing companies in the basic industrial sector and chemicals on the IDX. Using purposive sampling technique was applied
to determine the sample. The sample in this study were the basic industrial and chemical soup manufacturing companies listed on
the IDX and met the criteria. The number of samples used was 93 financial statements based on predetermined criteria. Data were
collected using the documentation method measured by a ratio scale. The results showed that company size has a positive and
significant effect on audit delay which is indicated by a significant value of 0.0462 , profitability has a significant negative effect
on audit delay with an alpha value of 0.0047 , and auditor switching has no significant effect on audit delay. with negligent 0.5687.

Keywords: Profitability; Firm Size; Auditor Switching; Audit Delay

\section{PENDAHULUAN}

Perkembangan perusahaan Go publik mengalami kemajuan yang sangat cepat begitu juga di Indonesia dan peningkatan signifikan. Perkembangan ini menyebabkan terjadinya peningkatan terhadap permintaan pengauditan laporan keuangan perusahaan. Dalam pasar perputaran modal, persyaratan utama untuk menaikkan harga saham satu perusahaan adalah pada kesesuaian waktu perusahaan untuk menyajikan laporan keuangannya beserta dengan laporan audit perusahaan itu (Halim.V, 2000).

Karena banyaknya perusahaan Go publik sehingga kebutuhan untuk pengauditan laporan keuangan semakin bertambah (Prabasari \& Merkusiwati, 2017). Dan untuk mengetahui bagai mana kondisi dari perusahaan tersebut di lihat berdasarkan laporan keuangan telah melalui proses pengauditan. Dan hasil terakhir dari proses akuntansi merupakan laporan keuangan yang sudah melalui proses pengauditan (Abin \& Nabawi, 2014). Yang dijadikan sebagai sumber pemberi informasi kepada para investor - investor, masyarakat umum, calon Investor, manajemen, dan para pengguna lainnya untuk mengambil atau menentukan sebuah keputusan (Yoga \& Widhiyani, 2017).

Serta (Harjanto, 2017) perusahaan Go publik akan mendapatkan banyak manfaat, namun di lihat dari sisi lain memberikan konsekuensi untuk perusahaan yaitu konsekuensi pengambilalihan. Investor juga memiliki kontrol atas perusahaan, serta konsekuensi lain yang di hadapi oleh perusahaan adalah perusahaan harus mengikuti peraturan mengenai pasar modal karena perusahaan yang tergabung telah menyetujui ketetapan dan ketentuan yang tetapkan saat perjanjian.

Pengauditan laporan keuangan memerlukan rentang waktu, rentang waktu yang di perlukan dalam proses pengauditan laporan keuangan di sebut dengan audit delay. Sedangkan keprofesionalan seorang auditor bisa dilihat berdasarkan ketepatan waktu untuk proses pengauditan oleh seorang auditor. Dalam penyampaian atau mengumumkan laporan keuangan oleh perusahaan kepada pengguna tergantung pada ketepatan waktu seorang auditor menyelesaikan proses pengauditan, bagi sebuah perusahaan waktu yang cepat dan sesuai untuk melakukan pengauditan laporan keuangan oleh auditor angan di utamakan, terlebih untuk perusahaan go publik. Dengan adanya audit delay pada laporan keuangan membuat auditor dapat dengan tepat waktu menyelesaikan pekerjaannya (Eksandy, 2017).

Faktor internal dan faktor ekstern ikut mempengaruhi audit delay. Faktor internalnya berupa pengaruh ukuran perusahaan, profitabilitas perusahaan dan auditor switching (pergantian auditor) (Harjanto, 2017). 


\section{METODE PENELITIAN}

Data dalam penelitian ini adalah data sekunder. Perusahaan go publik di BEI menjadi sumber data untuk penelitian ini. Penelitian ini menggunakan waktu untuk melakukan observasi yaitu dari tahun 2017 - 2019. Proses pengumpulan data dalam melakukan penelitian yaitu dengan proses dokumentasi.

Pengujian penelitian ini di lakukan guna melihat pengaruh antara ukuran perusahaan, profitabilitas, dan auditor switching dengan faktor y audit delay pada perusahaan manufaktur sektor industri dasar dan kimia di BEI. Dengan demikian penelitian ini di golongkan ke dalam penelitian kuantitatif dengan data panel dan untuk mengukur data dengan menggunakan skala rasio.

Penelitian ini menggunakan populasi dan sampel di ambil dari data berdasarkan pada BEI. Dengan menggunakan sebanyak 74 perusahaan sebagai populasi. Perusahaan objek di seleksi sesuai dengan kriteria yang ditentukan atau di sebut juga dengan kriteria proposive sampling. Dan setelah di lakukan seleksi tersebut sehingga di dapatkan 31 perusahaan memenuhi kriteria porposive sampling. Untuk menentukan perusahaan yang di teliti maka di gunakan kriteria porposive sampling, yaitu: 1) perusahaan manufaktur listed pada sektor yang telah di tentukan dan terdaftar di BEI. 2) perusahaan yang menerbitkan laporan keuangan lengkap pada periode 2017 - 2019. 3) Tidak adanya data ekstrim perusahaan selama periode penelitian dari tahun 2017 - 2019. 4) perusahaan tidak melakukan delisting selama periode penelitian. Penelitian ini menggunakan defensi operasional variabel di bedakan antara variabel dependen dan independen.

Tabel 1. Definisi Operasional Variabel

\begin{tabular}{|c|c|c|c|}
\hline No & Variabel & Pengertian & Indikator \\
\hline 1 & $\begin{array}{l}\text { Audit } \\
\text { Delay } \\
(Y)\end{array}$ & $\begin{array}{l}\text { Perbedaan waktu antara tanggal laporan keuangan } \\
\text { dengan tanggal laporan audit independen } \\
\text { (Saemargani \& Mustikawati, 2015) }\end{array}$ & $\begin{array}{l}\text { Selisih hari antara tanggal penerbitan } \\
\text { laporan keuangan dengan laporan audit }\end{array}$ \\
\hline 2 & $\begin{array}{l}\text { Ukuran } \\
\text { perusahaan } \\
\text { (X1) }\end{array}$ & $\begin{array}{l}\text { Pengelompokan perusahaan berdasarkan besar } \\
\text { kecilnya Perusahaan tersebut } \\
\text { (Eksandy, 2017) }\end{array}$ & $\begin{array}{l}\text { Ukuran perusahaan }=\text { logaritma } \\
\text { natural total aset }\end{array}$ \\
\hline 3 & $\begin{array}{l}\text { Profitabilit } \\
\text { as } \\
\text { (X2) }\end{array}$ & $\begin{array}{l}\text { Kemampuan perusahaan dalam memanfaatkan aset } \\
\text { untuk mencapai keuntungan atau laba } \\
\text { (Rachmawati, 2008) }\end{array}$ & $R O A=\frac{\text { Laba Bersih }}{\text { Total Aset }}$ \\
\hline 4 & $\begin{array}{l}\text { Auditor } \\
\text { Swiching } \\
\text { (X3) }\end{array}$ & $\begin{array}{l}\text { Pertukaran auditor dan partner audit atau KAP oleh } \\
\text { perusahaan atau klien } \\
\text { (Wiryakriyana \& Widhiyani, 2017) }\end{array}$ & Variabel dummy \\
\hline
\end{tabular}

Penelitian ini melakukan pengujian hipotesis guna melihat melihat seberapa besar pengaruh likuiditas variabel $\mathrm{X}$ (ukuran perusahaan, profitabilitas, dan auditor switching) terhadap variabel (audit delay). Penelitian ini melakukan penggabungan antara data Time series dengan data Cros section atau data panel. Perusahaan yang di jadikan sampel dalam penelitian ini adalah sebanyak 93 perusahaan.

Metode statistik deskriptif adalah metode yang di gunakan dalam penelitian ini. Untuk pengelolaan regresi data panelnya menggunakan eviews.

Analisis regresi data panel menggunakan pendekatan yaitu CEM, FEM, REM (Qusibah \& Yusra, 2019). Untuk menemukan model terbaik dapat dilakukan dengan dua tahapan yaitu dengan cara uji Chow yaitu untuk melihat yang terbaik antara MODEL CEM dengan FEM. Serta Uji Hausman, dilakukan untuk menentukan model mana yang terbaik digunakan antara model FEM dengan Model REM. Model regresi yang baik harus menghasilkan estimasi linear tidak bias (Best Linear Unbiased Estimator) (Qusibah \& Yusra, 2019).

\section{HASIL DAN PEMBAHASAN}

\section{Uji Deskriptif Statistik}

Tabel 2. Deskriptif Statistik

\begin{tabular}{ccccc}
\hline & $\begin{array}{c}\text { Ukuran } \\
\text { perusahaan }\end{array}$ & Profitabilitas & $\begin{array}{c}\text { Auditor } \\
\text { Switching }\end{array}$ & Audit Delay \\
\hline Maksimum & 33,4668427 & 13,01 & 1 & 100 \\
Minimum & 24,4170059 & $-13,58$ & 0 & 69 \\
Mean & 28 & 2 & 1 & 82 \\
Standar Deviasi & 1,785535761 & 5,321936959 & 0,502680984 & 5,806506805 \\
Observasi & 93 & 93 & 93 & 93 \\
\hline
\end{tabular}

Tabel tersebut menunjukkan bahwa observasi yang berjumlah 93 laporan keuangan perusahaan. Menunjukkan bahwa nilai maksimum dari size adalah sebesar 33,4668427 atau senilai RP 342.345.883.000.000 yaitu Unggul Indah 
Cahaya Tbk pada tahun 2019, dengan nilai minimum dari size sebesar 24,4170059 atau Rp 40.194.897.678 yaitu Siwani Makmur Tbk pada tahun 2017 dan rata - rata dari size perusahaan tersebut tersebut adalah 28 dan standar deviasinya senilai 1,785535761 .

Nilai maksimum dari ROA perusahaan yang di analisis tersebut adalah 13,01 yang di dapatkan oleh perusahaan Charoen Pokphand Indonesia Tbk pada tahun 2019 dan nilai minimum sebesar -13,58 yang di dapatkan oleh perusahaan Keramika Indonesia Assosiasi Tbk pada tahun 2017 dengan nilai rata- rata ROA sebesar 2, serta standar deviasi sebesar 5,321936959.

Nilai auditor switching atau pergantian auditor menggunakan variabel dummy sebagai alat ukur data. Nilai maksimum sebesar 1 untuk menyatakan perusahaan yang melakukan pergantian auditor tahun sebelumnya dengan auditor yang baru, untuk perusahaan yang tidak melakukan audit delay di gunakan nilai minimum 0. Dan nilai ratarata auditor switching adalah 1 , serta standar deviasinya sebesar 0,502680984 .

Berdasarkan tabel uji statistik deskriptif menunjukkan nilai maksimum dari audit delay sebesar 100 hari yaitu laporan audit perusahaan Gunawan Dian jaya Steel Tbk tahun 2019 dan minimum audit delay adalah 69 hari yaitu laporan audit perusahaan Siwani Makmur Tbk pada tahun 2017. Dan rata - rata audit delay pada laporan audit perusahaan yang di analisis sebesar 82 hari dan standar deviasi sebesar 5,806506805.

\section{Uji Lanjut}

Tabel 3. Uji Chow (Likelihood Test Ratio)

\begin{tabular}{lrrr}
\hline \multicolumn{1}{c}{ Effects Test } & \multicolumn{1}{c}{ Statistic } & \multicolumn{1}{c}{ d.f. } & \multicolumn{1}{c}{ Prob. } \\
\hline Cross-section F & 3.185685 & $(30,59)$ & 0.0001 \\
Cross-section Chi-square & 89.569520 & 30 & 0.0000 \\
\hline
\end{tabular}

Berdasarkan data yang uji menunjukkan prob < alpa $(0,0000<0,05)$. Dari pengujian yang telah di lakukan maka dapat di simpulkan bahwa fixed effect model lebih baik.

Tabel 4. Uji Husman

\begin{tabular}{crrr}
\hline Test Summary & Chi-Sq. Statistic & Chi-Sq. d.f. & Prob. \\
\hline Cross-section random & 3.964856 & 3 & 0.2653 \\
\hline \multicolumn{4}{c}{ Sumber: Data sekunder yang di olah dengan eviews }
\end{tabular}

Berdasarkan data yang di uji menunjukkan nilai probability pada Cross-section rendom lebih besar dari pada nilai alpa $0,2653>0,05$. Dapat di simpulkan bahwa uji yang layak di gunakan adalah Rendom Effect Model.

Nilai Probability Jarque-Bara hitung sebanyak 0,733996 > 0,05 sehingga di simpulkan residual telah terdistribusi dengan normal dalam artian bahwa untuk uji asumsi klasik dari kenormalan data ini telah terpenuhi.

\section{Pemilihan Model Terbaik}

Dari uji yang di lakukan yaitu pertama dengan melakukan pengujian dengan Chow Test yaitu menguji antara CEM dengan FEM dan di dapatkan model yang layak adalah FEM, sehingga di lanjutkan dengan melakukan uji hausmant Test yaitu melakukan pengujian antara model FEM dengan REM dan berdasarkan uji tersebut model yang layak adalah REM. Berdasarkan uji lanjut yang di lakukan tersebut sehingga di dapat Ian REM sebagai model terbaik.

\section{Analisis Regresi Data Panel}

Teknik analisis yang di gunakan dan di laksanakan yaitu dengan cara mengolah dan membahas sampel yang telah di peroleh dan di gunakan untuk menilai hipotesis yang diduga. Variabel C merupakan Constant (konstan) variabel Y adalah Audit Delay, variabel X1 adalah Ukuran Perusahaan, variabel X2 adalah Profitabilitas dan variabel X3 adalah Auditor Switching. Dengan hasil sebagai berikut:

Tabel 5. Hasil Estimasi Regresi Data Panel dengan Metode Rendom Effect Model

\begin{tabular}{cc}
\hline Variabel & Koefisien \\
\hline Konstanta & 58,01626 \\
Ukuran Perusahaan & 0,871258 \\
Profitabilitas & $(-0,347418)$ \\
Auditor Switching & 0,539246 \\
\hline
\end{tabular}

Berikut ini adalah persamaan regresi data panel rendom effect model adalah :

\section{Yit $=58,01626+0,871258 \times 2-0,347418 \times 2+0,539246 X 3+$ eit}

Berdasarkan model persamaan regresi dapat di jelaskan bahwa Hasil uji analisis regresi berganda terlihat bahwa nilai konstanta sebesar 58,01626 dengan arti bahwa tanpa adanya pengaruh dari variabel bebas yaitu ukuran perusahaan, profitabilitas, dan auditor switching maka audit delay akan bernilai sebesar 58,01626.

Koefisien X1 atau ukuran perusahaan di peroleh sebesar 0,871258 dengan artian bahwa jika variabel ukuran perusahaan meningkat satu - satuan maka variabel audit delay meningkat sebesar 0,871258 dengan asumsi variabel lain konstan. 
Koefisien X2 atau profitabilitas di peroleh sebesar 0,347418 dengan arti setiap peningkatan profitabilitas meningkat satu - satu maka variabel audit delay menurun sebesar 0,347418 dengan anggapan variabel lain dalam bentuk konstan.

Koefisien X3 atau Auditor Switching di peroleh sebesar 0,539246 hal ini menunjukkan bahwa jika variabel ukuran perusahaan meningkat satu - satuan maka variabel audit delay meningkat sebesar 0,539246 dengan asumsi variabel lain konstan.

\section{Uji Hipotesis}

Tabel 6. Pengujian Hipotesis (Uji T) dengan Model Random Effect Model

\begin{tabular}{lcccccc}
\hline \multicolumn{1}{c}{ Variabel } & Koefisien & t-statistik & t-tabel & Prob & Alpha & Kesimpulan \\
\hline Ukuran Perusahaan & 0.871258 & 2.021484 & 1.986979 & 0.0462 & 0.05 & H1 Diterima \\
Profitabilitas & $(-0.347418)$ & $(-2.900421)$ & 1.986979 & 0.0047 & 0.05 & H2 Diterima \\
Auditor Switching & 0.539246 & 0.572129 & 1.986979 & 0.5687 & 0.05 & H3 Ditolak \\
\hline
\end{tabular}

Dari tabel di atas variabel ukuran perusahaan menunjukkan nilai T hitung lebih besar secara absolut dari ukuran perusahaan kecil dari alpa $(0,0462<0,05)$ maka kesimpulannya Ho di tolak dan Ha dapat di terima. Variabel profitabilitas menunjukkan nilai T hitung lebih besar secara absolut dari Profitabilitas kecil dari alpa $(0,0047<0,05)$ maka kesimpulannya Ho di tolak dan Ha dapat di terima. variabel auditor switching menunjukkan nilai T hitung lebih besar secara absolut dari auditor switching lebih besar dari alpa $(0,5687<0,05)$ maka dapat di simpulkan Ho di tolak dan Ha dapat di terima. Sehingga ukuran perusahaan berpengaruh positif terhadap audit delay. Sedangkan adanya pengaruh negatif signifikan oleh profitabilitas terhadap audit delay. Dan auditor switching tidak berpengaruh signifikan terhadap audit delay.

Adjusted $R$-suared sebesar 0,083494\% menjelaskan bahwa kemampuan variabel nilai panel menjelaskan variasi belanja modal sebesar 8,35\% sedangkan sisanya 91,65\% (100-8,35\%) dijelaskan oleh variabel lain yang tidak di masukkan dalam model atau di jelaskan oleh indikator atau terjadi karena adanya penyebab lain di luar dari penelitian ini. Berdasarkan hasil olah data statistik maka dapat disimpulkan:

1. Dari penelitian yang telah di lakukan atau di laksanakan pengujian terhadap 31 perusahaan dengan 93 data observasi yang di dapatkan dari situs BEI dan dari hasil uji yang di lakukan menunjukkan nilai signifikan ukuran perusahaan sebesar 0,0462 < 0,05 sehingga dapat di simpulkan bahwa H1 dalam pengujian hipotesis ini di terima dapat di katakan bahwa adanya pengaruh positif signifikan oleh ukuran perusahaan terhadap audit delay. Perusahaan go publik akan cepat untuk mempublish laporan keuangannya. Perusahaan tersebut ingin mendapatkan kepercayaan dari para investor bahwa perusahaan mereka dapat menyelesaikan laporan keuangan secara tepat waktu dengan demikian investor dan pengguna laporan keuangan lainnya dapat mengakses laporan keuangan dengan cepat dan mendapatkan informasi dengan cepat. Dan perusahaan mendapatkan investor penambahan modal perusahaan. Penelitian ini sama dengan penelitian yang di lakukan oleh (Rachmawati, 2008), (Lusiana \& Rahma, 2017) dan penelitian (Puspitasari \& Sari, 2012) yang menyatakan bahwa adanya pengaruh positif signifikan oleh ukuran perusahaan terhadap audit delay. Pengaruh ini di tunjukan dengan semakin besar nilai aset perusahaan tersebut maka semakin kecil kemungkinan terjadinya audit delay hal ini karena sumber daya manusia yang di miliki oleh perusahaan telah terlatih dan memudahkan proses pengauditan laporan keuangan.

2. Berdasarkan hipotesis ke2 yaitu pengaruh profitabilitas terhadap audit delay. Berdasarkan uji nilai t hitung pada variabel profitabilitas membuktikan bahwa $\mathrm{H} 2$ di terima. Dengan arti adanya pengaruh yang negatif signifikan oleh profitabilitas terhadap audit delay. Hasil penelitian ini sesuai dengan penelitian (Prabasari \& Merkusiwati, 2017), (Eksandy, 2017), dan hasil penelitian (Abin \& Nabawi, 2014) yang menyatakan bahwa profitabilitas berpengaruh negatif terhadap audit delay. Supaya laporan keuangan yang di miliki perusahaan tersebut dapat di lihat oleh investor - investor atau pencari informasi lainnya sehingga perusahaan bisa mendapatkan tambahan dana atau modal untuk perusahaannya dengan cepat. Karena perusahaan yang mengalami kerugian cenderung melalaikan untuk menyampaikan ke publik laporan keuangan perusahaannya. Karena perusahaan akan mendapatkan pandangan negatif dari stakeholder. Akuntan yang melakukan pengauditan terhadap laporan keuangan tersebut akan sangat berhati - hati dalam proses pengauditan terutama untuk menilai bagian - bagian yang menjadi penyebab kerugian. Dan untuk melihat apakah adanya penyelewengan sehingga membuat perusahaan mengalami kerugian. Namun hasil dalam penelitian ini berbeda dengan penelitian yang di lakukan oleh (Harjanto, 2017) yang berpendapat bahwa tidak ada pengaruh yang signifikan oleh profitabilitas terhadap audit delay. Karena perlahan yang mengalami kerugian atau yang mendapatkan laba tidak memberikan pengaruh atas keterlambatan penyampaian laporan keuangan perusahaannya ke publik.

3. Hipotesis ke 3 yaitu auditor switching berpengaruh positif terhadap audit delay. Dan berdasarkan hasil dari penelitian di dapatkan bahwa nilai t hitung untuk auditor switching bahwa $\mathrm{H} 3$ ditolak dan membuktikan bahwa tidak ada pengaruh yang signifikan antar auditor switching dengan audit delay. Kemungkinan bahwa adanya faktor lain yang menyebabkan terjadinya audit delay. Akuntan yang di tunjuk atau di pilih untuk melakukan pengauditan laporan keuangan sebuah perusahaan telah memiliki kemampuan yang biasa di andalkan sehingga untuk melakukan adaptasi dengan sebuah laporan keuangan perusahaan tidaklah membutuhkan waktu yang lama. Akuntan yang melakukan pengauditan dapat dengan mudah menilai laporan keuangan perusahaan tersebut. Hasil 
penelitian (Shinta Widhiasari \& Budiartha, 2016), (Syofiana et al., 2016) dan (Putra \& Sukirman, 2014) mengemukakan pendapat yang sama. Menyatakan bahwa tidak adanya pengaruh antara pergantian auditor (auditor switching) dengan audit delay. Karena setiap auditor baru yang melakukan pengauditan pada laporan keuangan pasti telah mempelajari bagaimana laporan keuangan perusahaan tersebut, sehingga kemungkinan terjadinya audit delay dalam sebuah perusahaan bisa di minimumkan.

\section{KESIMPULAN}

Hasil penelitian dari ukuran perusahaan (X1), profitabilitas (X2), dan auditor switching (X3). Di simpulkan bahwa : Pertama berdasarkan hasil penelitian yang sudah di lakukan di dapatkan bahwa rata - rata untuk tingkat audit delay yang di lakukan oleh perusahaan sektor industri dasar dan kimia yang terdaftar di BEI pada tahun 2017 sampai dengan tahun 2019 yaitu 82 hari yang terhitung dari tanggal penerbitan laporan keuangan(tutup buku) hingga tanggal laporan audit. Kedua hasil dari penelitian ini juga sama dengan hasil dari penelitian (Rachmawati, 2008), (Lusiana \& Rahma, 2017), dan (Puspitasari \& Sari, 2012) yang menyatakan bahwa ukuran perusahaan berpengaruh positif terhadap audit delay. Hal ini karena perusahaan yang besar di anggap dapat mengontrol perusahaan dengan baik dan bisa menyelesaikan proses pengauditannya dengan tepat waktu. Ketiga dari pengujian yang telah di lakukan di dapatkan bahwa profitabilitas berpengaruh negatif terhadap audit delay. Sama dengan penelitian (Prabasari \& Merkusiwati, 2017), (Eksandy, 2017), serta (Abin \& Nabawi, 2014) yang menyatakan bahwa profitabilitas berpengaruh negatif terhadap audit delay. Hal tersebut karena perusahaan yang mengalami kerugian terkesan akan menunda - nunda penyampaian laporan keuangannya. Karena akan mendapatkan pandangan tidak baik dari investor. Serta akuntan dalam melakukan proses pengauditan akan sangat berhati - hati dap harus teliti dalam pengauditan laporan keuangan perusahaan tersebut. Keempat hasil penelitian menyatakan bahwa auditor switching tidak berpengaruh signifikan terhadap audit delay. Dan hasil penelitian tersebut bertolak belakang dengan penelitian yang di gunakan untuk hipotesis sebelumnya. Karena akuntan yang di pilih untuk melakukan proses pengauditan dapat beradaptasi dengan mudah dengan laporan keuangan perusahaan tersebut. Sehingga pergantian auditor dalam perusahaan bukanlah faktor terjadinya audit delay.

\section{REFERENCES}

Abin, S., \& Nabawi, eki muhamad. (2014). Pengaruh Return on Assets, Debtt to Assets Ratio, dan Opiini Audit Terhadap Audit Delay. STIE Muhamadiyah Bandung, 1-9.

Eksandy, A. (2017). Pengaruh Ukuran Perusahaan, Solvabilitas, Profitabillitas dan Komite Audit Terhadap Audit Delay. Competitive Jurnal Akuntansi Dan Keuangan, 1(2).

Halim.V. (2000). Faktor-Faktor yang Mempengaruhi Audit Delay: Studi Empiris pada Perusahaan-perusahaaan di Bursa Efek Jakarta. Jurnal Bisnis Dan Akuntansi, 2(1), 63-75.

Harjanto, K. (2017). Pengaruh Ukuran Perusahaan, Profittabilitas, Solvabilitas, dan Ukuran Kantor Akuntan Pablik terhadap Audit Delay. Ultima Accounting, 9(8), 33-49.

Lusiana, \& Rahma, A. A. (2017). Pengaruh Firrm Size, Profitability, Audit Committee Size, Dan Auditor Opinion Terhadap Audit Delay Pada Perusahaan LQ-45 Yang Terdaftar Di Bursa Efek Indonesia Tahun 2011-2015. Issn: 2502-8774, 24(1), 191-205.

Prabasari, i . g. . ayu ratih, \& Merkusiwati, n. k. lely aryani. (2017). Pengaruh Profitabiliatas, Ukuran Perusahaan, Dan Komita Audit Pada Audit Delay Yang Dimoderasi Oleh Reputasi Kap. E-Jurnal Akuntansi Universitas Udayana, 20, 1704-1733.

Puspitasari, E., \& Sari, N. A. (2012). Pengaruh Karakteriistik Perusahaan Terhadap Lamanya Waktu Penyelesaian Audit ( Audit Delay ) Pada Perusahaan Manufaktur Yang Terdaftar Di Bursa Efek Indonesia. Jurnal Akuntansi \& Auditing, 9(1), 31-42.

Putra, A. B. S., \& Sukirman. (2014). Opini Auditor, Laba Atau Rugi Tahun Berjalan, Auditor Swiching Dalam Memprediksi Audit Delay. Accounting Analysis Journal, 3(2), 187-193.

Qusibah, V. L., \& Yusra, I. (2019). Profitabilitas, dan Ukuran Perusahaan Sebagai Faktor Penentu Levarege Perusahaan Di Indonesia. Jurnal Pundi, 03(01), 13-26. https://doi.org/10.31575/jp.v3i1.125

Rachmawati, S. (2008). Pengaruh Faktor Internal dan Ekssternal Perusahaan Terhadp Audit Delay. Akuntansi Dan Keuangan, 10, 1-10. https://doi.org/10.9744/jak.10.1.pp. 1-10

Ratnaningsih, N. M. D., \& Dwirandra. (2016). Spesialisasi Auditor Sebagai Variable Pemoderasi Pengaruh Audit Tenuree Dan Pergantian Auditor Pada Audit Delay. E-Jurnal Akuntansi Universitas Udayana, 16, 18-44.

Rustiarini, N. W. W., \& Sugiarti, M. (2011). Pengaruh Karakteristik Auditor, Audit Tenure, Pergantian Auditor pada Audit Delay. Ilmiah Akuntansi Dan Humaniika Jinah, 2(C), 657-675.

Saemargani, F. I., \& Mustikawati, I. (2015). Pengaruh Ukuran Perusahaan, Profitabilitas, Solvabilitas Dan Opini Auditor Terhadap Audit Delay. Jurnal Nominal, 4(2). https://doi.org/10.25139/jaap.v2i2.1397

Shinta Widhiasari, N. M., \& Budiartha, I. K. (2016). Pengaruh Umur Perusahaan, Ukuran Perusahaan, Reputasi Auditor Dan Pergantian Auditor Terhadp Audit Report Lag. E-Jurnal Akuntansi Universitas Udayana, 15, 200-227.

Syofiana, E., Suwarno, \& Hariyono, A. (2016). Pngaru Financial Distress, Auditor Switching Dan Audit Fee Terhadap Audit Delay Pada Perusahaan Manufaktur Yang Terdaftar Di Indeeks Saham Syariah Indonesia. (X), 1-21.

Wiryakriyana, anak agung gede, \& Widhiyani, ni luh sari. (2017). Pengaruh Ukuran Perusahaan, Leverage, Auditor Switching, dan Sistem Pengendalian Internal Pada Audit delay. E-Jurnal Akuntansi Universiitas Udayana, 19(1), 771-798.

Yoga, darmawan. . putu, \& Widhiyani, ni luh sari. (2017). Pengaruh Ukuran Perusahan, Komplikasi Perusahaan dan Komite Audit pada Audit Delay. E-Jurnal Akuntansi Universtas Udayana, 21, 254-282. 